B 112

\title{
文化情報を分析するためのビジュアルデータマイニング環境
}

\author{
小山田耕二0 (京都大学), 坂本尚久(京都大学)
}

\section{Visual Data Mining Environment for Japanese Cultural Information}

\author{
Koji KOYAMADA, Naohisa SAKAMOTO
}

\begin{abstract}
概要
本報告では日本文化の背景を分析するためのビジュアルデータマイニング環境について述 べる．日本文化に関する情報からの普遍性を抽出するには，得られた文化情報への多元的な 分析が不可欠である. 分析手法の一つとして，情報可視化の手法を用い，人間の視覚情報処 理による普遍性の抽出を支援する研究を計画している，類似研究として，UCSDにおける "Cultural Analytics"プロジェクトでは，経済，社会学，そして歴史に関するコンテンツをタ イルド表示装置上に表示して，文化情報の分析を支援する環境を構筑している，我々は，日 本文化の情報加らの普遍性を抽出する手段のひとつとして, 日本文化情報における漢字の表 意に着目した基底関数セットの抽出とその適用を考える、このことを支援するために，漢字 空間において，歌集をひとつの詩を粒子に対応させた粒子群として表現し，ボリューム可視 化手法を用いて可視化する予定である.
\end{abstract}

Keywords: Tiled display wall, large`scale volume rendering

1.はじめに

ビジュアルデータマイニングの対象がボリュームデー タ以外に拡張している，そのひとつとして文化情報が注 目されている，文化情報からの普遍性を抽出するには， 得られた文化情報への多元的な分析が不可欠である.分 析手法の一つとして，情報可視化の手法を用い，人間の 視覚情報処理による普㣂性の抽出を支援する枠組みが有 用とされている。

文化情報からの普遍性抽出のひとつとして, 日本文化 情報における漢字の表意に着目した基底関数セットの抽 出とその適用を考える，本研究では，漢詩・和歌・連歌 ・俳諧・俳句のデータベースを対象に，歌集の特徽を抽 出する問題を扱う．1つの歌集に表れるパターンの数は 数十万にものぼるため，そのすべてを研究者が吟味する ことは，現実的には不可能である，そこで，その大量の パターンの中から「重要」と思われるものだけを，数百 程度のオーダーで自動抽出するためのビジュテルデータ マイニング環境の櫵築を考える.これが可能となれば， 研究者はそれらのパターンを重点的に吟味することによ り，基底関数の抽出について有用な知胃を得ることがで きるものと期待する、このことを実現するために，漢字 空間において，歌集をひとつの詩を粒子に対応させた粒 子群として表現し，粒子ボリュームレンダリング手法を 用いて可視化する。

本研究では，歌集の粒子ボリュームレンダリング結果 以外に違ったフォーマット（グラフィクス，テキスト， 数字, 画像, 映像, 時系列グラフ, 地図, 時空間インタ
フェース) で表現された多くの属性をもった情報を効果 的に蒜示しないといけない。このような情報は規模の大 きな文脈の上で配固されるほうが效果的である，したが って，可視化表現は，ギガピクセル級のウォールサイズ の表示装置（タイルド表示装道）を最大限に活用できよ うなデザインを考慮する。たとえば, Calit2(UCSD)では， 経済，社会学、そして歴史に関するコンテンツをタイル ド表示装贯上に表示して，文化情報の分析を行う研究プ ロジェクトが進行中である川，Calit2(UCSD)では，文化 情報の可視化においてタイルド表示装圈を有效活用して いる事例が報告されている。

\section{2. 文化情報可視化}

文化情報の可視化技術における研究開発では以下の 観点での問いが重要とされる.

1. 文化的な価做像造について測定可能な指標をど う定義すればよいのか？

2. 世界的文化創造や消費について実時間表示する ための枠組みを持っているか? 文化的考え・函像 ・流行についての流れを可視化できるのか?

3. 文化的な生活嗜好についての時閒的変化を視覚 的に表現することができるのか？

今日科学・ビジネス・政府・その他の機関は巨大デー タとその流れについて可視化とベースとした分析に頼っ ている. 彼らは統計的データ分析. データマイニング. 情報可視化・科学的可視化・視覚解析, そしてシミュレ ーション技術を利用している。これらの技術を文化情報 
に適用し始める時期が来たものと理解している，その巨 大データは寸でに存在している，博物館・図書館・企 業によってここ10年間で行すれた電子化作業（グーグル やアマソンの書籍スキャニング等)、ウェブ上で日々利用 可能となっている文化的コンテンツ（2008年2月時点で Flicrは12億もの画像ファイルがューザやシステムによ ってつけられたタグ情報とともに保存されている）の爆 発的な增加を想像するとそのことが理解できる

科学的可視化において使执たデータセットのサイズ に匹敵する規模の巨大データ（数十テラバイト級）の分 析に基づいて文化的流れ，パターン，関連についての詳 練で対話的な可視化が可能になるものと予想する．コノ データセットはさまざまなところから沸きあがってくる 第一の源は，ゲーム，ビジュアルデザイン，音楽，ビ デオ, 写真, 芸術作品, 建築物の写真, 空間設計，ブロ グ, ウェブページなどのメディアコンテンツである。こ のようなコンテンツを可視化する上において現存する夕 グ情報（ユーザによって明示的に付与されたもの）だけ でなくメディアコンテンツを分析して新たに生成する夕 グ情報(コンピュータビジョン技術を使って発見される 特徴情報）も使うことになるであるう。第二の源は，人 タがこれらのコンテンツについて議諭, 創造, 出版, 利 用，共有，編集，合成した際に残していく電子的トレ一 ス情報である，第三の源は，多くの分野において，文化 的咴好・流行，文化情報の利用に関して作成された統計 情報を提供するウェブ情報である。ささらにメタチャネル と呼ぶ情報（さまざまな文化的分野でもっとも與味深い 発展を追跡するブログ）も源となろう。

可視化は違ったフォーマット（グラフィクス，テキス 卜，数字，画像，映像，時系列グラフ，地図，時空間イ ンタフェース）で表現された多くの属性をもった情報を 提供しないといけない，この情報は規模の大きな文脈の 上で配置されるだろう。たとえば, 経済, 社会学, そし て歴史に関寸るデ一タが地図上に表示されるという状況 である.また，可視化はギガピクセル級のウォールサイ ズの表示装置を最大限に活用できようなデザインを考虑 すべきである。もちろん通常表示装置や携带電話画面も 想定した詳細度制御も考慮しないといけない。

現在の文化情報可視化手法では単一の時系列データの みを表示対象としたり，特定のデータに特化した手法と なってることが多いが，本研究の目標は、ニーザが違っ た種類のデータやメディア（オリジナルの文化コンテン ッ，会話，時空に関少る文化的パターン，統計情報など ）を統合表示できるようなオープンでモジュ一ル構成の 文化情報可視化環境を搆筑することである。ユーザは自 分自身で可視化を開始点（GISなど）としたデータ分析 を行えるようになるべきである，計算機の処理能力が向 上寸れば，このような分析は実時間またはそれに近い速 さで夷施されることになるであるう。これらのデータセ ット沈入手前，またはウェブから採取される前に統合化
されるようになると予測する，理想的にはユーザが新し い文化情報データベースを接続し，それに対応する新 しい視覚的分析モジュールを追加できるよう十分に柔軟 でないといけない.

\section{3. 漢字空間における俳句情報可視化}

本研究では漢詩が和歌・連歌・俳諧・俳句という変遷 を辿った軌跡を可視化して日本文化の基底を浮き歴りに する。連歌 (れんが) は鎌倉時代ごろから興り、南北朝 時代加ら室町時代にかけて大成された、日本の伝統的な 詩形の一種である。これは，和歌のつよい影響のもとに 成立し、後に俳諧の連歌や発句（俳句）がここから派生 している。俳諧（はいかい）とは、主に江户時代に栄え た日本文学の形式であり，誹諧とも表記する。俳句（は いく）とは五・七・五の音節から成る日本語の定型詩で あり、世界最短の詩である。

日本文化の基底を探索するにあたり，特に“弱さ”の 観点で日本文化の分析活動を支援する環境を構築する. 松岡は，弱さが社会文化経済のさまざまな場面で決定的 な役割を演じてきたとした ${ }^{2 !}$. 漢字に薄弱・断片・あや うさ・暧昧・境界・翼端といった弱さを表現する属性で その段階値を設定し，その属性を座標軸とするような漠 字空間に，俳句の脚結（あゆひ）の効能を指標化したも のを色つき粒子として表現寸る. 江戸時代の言語学者富 士谷御杖による著書「脚結抄」で議論された日本語の「て にをは」のことを脚結という，俳句ではこのあゆひが季 語のイメージを若干崩しそこにできたわずかな腺間に骶 通を持ち込む．大野晋による著書「倸り結びの研究」に よれば日本語は，俳句にお污る切字や助詞の一字で文脈 がかわつてしまう3．この脚結の效能を可視化する。

粒子ボリュームレンダリングは，アンサンブル平均に より与えられた空間を確率的に可視化子る特長がある ${ }^{4)}$ このため従来のいわゆる決定論的な可視化手法とは違っ て融通の持ち込まれた空間の可視化に適するものと考え る、これまでこの粒子ボリュームレンダリングは 3 次元 空間で表現されたスカラデータを可視化してきた。これ を多次元（薄弱・断片・あやうさ・曖昧・境界・異端等） で表現された脚結の効能を可視化できるように拡張する。

\section{参 考 文 献}

1) Lev Manovich. "Cultural Analytics: Visualing Cultural Patterns in the Era of "More Media. DOMUS, 2009.

2) 坂本尚久，小山田耕二，粒子ベースボリュームレンダリン グ，可視化情報学会論文誌，Vol.27, No.2, pp.7-14, 2007.

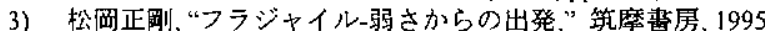

4）大轱留,”倸り結びの研究,"岩波書店, 1995 